\title{
Ruské a české syntaktické termíny ve srovnávacím pojetí
}

БЕРГЕР, О.: Синтаксические термины в русском и чешском языках: сопоставительный аспект (на материале выбранных терминов). Brno: Masarykova univerzita 2021, 141 s. ISBN 978-80-210-9807-7.

Je potěšitelné, že během jednoho roku byla lingvistická rusistika obohacena o dvě publikace tematicky zaměřené na problematiku syntaxe, navíc $\mathrm{v}$ rusko-českém srovnávacím plánu. Syntax stejně jako morfologie se v současné době nacházejí spíše na okraji odborného zájmu našich rusistů, takže nové práce z oblasti gramatiky lze jenom přivítat.

Loni v létě vyšla monografie mladého olomouckého rusisty Václava Slováka Synkretizmus větných členů v ruštině a češtině, ${ }^{1}$ kde se nově řeší problematika pojetí nejednoznačných větných členů v ruské a české syntaxi ${ }^{2}$.

Letos je to rusky psaná lexikálně-syntaktická práce mladé brněnské rusistky Olgy Berger Синтаксические термины в русском и чешском языках: сопоставительный аспект (на материале выьранных терминов), ${ }^{3}$ která je tématem této recenze.

Vzhledem $\mathrm{k}$ velkému rozsahu syntaktické terminologie se O. Berger rozhodla omezit svůj výzkum pouze na terminologii tří pro syntax zásadních oblastí, a to jak z obecné syntaxe, tak ze syntaxe jednoduché věty. Obecné syntaktické terminologie se týkají první dva okruhy - vztah slovního spojení a syntagmatu a syntaktické vztahy a prostředky pro jejich vyjádření, třetí je věnován větě jednoduché a jejím komponentům, tedy terminologii větných členů.

Aby mohl být zajištěn konfrontační aspekt tématu, je jazykový materiál pro zkoumání zvolených termínů excerpován z autorkou vhodně vybraných gramatik nebo syntaktických prací ruských syntaktiků ruštiny, českých rusistů-syntaktiků i českých bohemistů zabývajících se syntaxí. Každá skupina zahrnuje jak význačné práce starší - z 50.-60. let minulého století, tak práce novější - převážně z 80.-90. let, ale i z počátku tohoto století. Ze starších prací bylo zřejmě omylem opomenuto významné dílo brněnských autorů J. Bauera, R. Mrázka a S. Žaži Příruční mluvnice

1 SLOVÁK, V.: Synkretizmus větných členů v ruštině a češtině. Sinkretizm členov predloženija v russkom $i$ češskom jazykach. Olomouc: Univerzita Palackého v Olomouci, 2020.

2 Viz naši recenzi FLÍDROVÁ, H.: Nový pohled na větné členy v ruské a české syntaxi. Opera Slavica, 2021, 2, s. 73-76.

3 BERGER, O.: Sintaksičeskije terminy v russkom i češskom jazykach: sopostavitel’nyj aspekt (na materiale vybrannych terminov). Brno: Masarykova univerzita 2021. 
ruštiny pro Čechy II - skladba, ${ }^{4} \mathrm{O}$. Berger však s těmito autory pracuje v souvislosti s jinými jejich pracemi.

Práce obsahuje čtyři stěžejní kapitoly, které jsou logicky uspořádány tak, že první je věnována otázkám terminologie obecně, zatímco následující tři kapitoly jsou již zaměřeny na konfrontační zkoumání syntaktické terminologie na základě vybraných excerpovaných termínů.

V první kapitole История изучения термина. Основные теоретические понятия терминоведения ${ }^{5}$ autorka nejprve sleduje historii zkoumání termínů v ruské i české lingvistice, uvádí významné autory i práce, zdařile se snaží postihnout mezi oběma lingvistickými tradicemi rozdíl v pojetí i zaměření jejich teoretického bádání, sleduje rovněž srovnávací terminologii. Dále je pozornost věnována samotnému termínu, jeho vlastnostem, definicím a zejména pak nevyřešeným problémům současné terminologie, jako napřr variantnost a synonymie, přičemž jsou průběžně brány v úvahu názory jak ruských, tak českých terminologů. V závěru se uvádějí základní premisy podstatné pro autorčino další bádání.

Druhá kapitola Словосочетание и синтагма в русских и чешских грамматиках 6 je zaměřena na výklad termínů синтагма а словосочетание - syntagma / větná dvojice a slovní spojení v ruských a českých gramatikách, a to jak z hlediska jejich obsahu, tak vzájemného vztahu. Jedná se o velmi složitou problematiku. Termíny jsou analyzovány postupně, nejprve v pracích ruských, poté českých a slovenských rusistů a nakonec českých bohemistů. Autorka správně nepokládá syntagma a slovní spojení za totožné gramatické fakty a na základě důkladného studia bohaté odborné literatury pracuje s řadou různých názorů a pojetí, pokouší se o jejich shrnutí a vymezení těchto termínů v ruské a české syntaktické tradici, což je obtížné. V práci je velmi dobře vyloženo dvojí rozdílné pojetí slovního spojení v ruské tradici, a to F. F. Fortunatova, jímž bylo považováno za základní jednotku syntaxe, a V. V. Vinogradova, který je pokládal za korelativní se slovem, což je bližší našemu chápání. Co se týče termínu syntagma, v naší tradici se vždy jedná o jednotku syntaktickou (Saussure, Bally, pražský strukturalismus), zatímco ruské tradici je odedávna vlastní především definice ve fonetickém smyslu (tj. rytmická jednotka, řečový takt) a teprve na druhém místě syntaktické pojetí, což O. Berger dokládá mimo jiné citací z nového ruského lingvistického encyklopedického slovníku. Současně si uvědomuje, že rozdíly mezi těmito gramatickými fakty navzájem i v každé ze sledovaných syntaktických tradic jsou velmi jemné, takže je nelze jednoznačně zobecnit.

4 BAUER, J. - MRÁZEK, R. - ŽAŽA, S.: Příruční mluvnice ruštiny pro Čechy. II, Skladba. Praha: Státní pedagogické nakladatelství, 1960.

5 Tamtéž, s. 12-40.

6 Tamtéž, s. 41-53. 
Ve třetí kapitole Типы синтаксических отношений и средства их выражения, синтаксические связи ${ }^{7}$ jsou popisovány syntaktické vztahy a zpo̊soby jejich vyjadřování v ruské i české tradici. Pozornost je zde logicky zaměřena zejména na nejdůležitější terminologický problém $\mathrm{v}$ tomto syntaktickém úseku, a to na rozdílné pojmenování prostředků realizujících syntaktické vztahy: $\mathrm{v}$ ruštině синтаксические связи a v češtině vyjadřovací prostředky/způsoby, což vyplývá z jejich odlišného pojetí a výkladu v české a ruské syntaxi, způsobuje to pochopitelně také problémy z hlediska didaktického. Sledovaná problematika je zde velmi dobře promyšlena a podrobně zkoumána, a to jak v pracích ruských rusistů, tak českých rusistů i českých bohemistů. V ruské syntaktické tradici se porovnáváním starších a novějších prací ukazuje, že termíny синтаксические отношения і синтаксические связи byly nejprve pojímány jako synonyma a teprve později začala být $\mathrm{v}$ prvním př́ípadě zdůrazňována obsahová stránka a ve druhém formální, užívané termíny se však nemění. V našich pracích se termíny pro vztahy a prostředky jejich realizace vždy lišily. Je chvályhodné, že O. Berger neopomenula uvést pro prostředky realizace koordinačních nebo subordinačních syntaktických vztahů také termíny parataxe a hypotaxe, s nimiž se pracuje v naší syntaktické tradici.

Nejobsáhlejší je čtvrtá kapitola Члены предложения, ${ }^{8}$ která obsahuje na základě vybraných syntaktických prací nejprve vymezení větných členů vůbec, poté hlavních i rozvíjejících větných členů s podrobným výkladem porovnávajícím jejich pojetí v obou syntaktických tradicích.

V rámci hlavních větných členů se podstatné rozdíly mezi termíny v ruské a české syntaxi týkají zejména termínů prísudek/predikát - сказуемое a termínů pro hlavní člen jednočlenných vět jednotný větný základ - главный илен / единый главный илен предложения. Zatímco v ruské syntaxi se s oběma termíny nadále pracuje, $\mathrm{v}$ naší rusistice se $\mathrm{v}$ poslední době místo termínu jednotný větný základ začal užívat termín predikát. Pod vlivem bohemistů se totiž ustoupilo od opozice vět dvojčlenných a jednočlenných (nyní věty podmětové a bezpodmětové), takže se termín predikát rozšriřil na oba větné typy a s termínem jednotný větný základ se již nepracuje. ${ }^{9}$ Tento terminologický rozdíl autorka názorně ukazuje v tabulce, ${ }^{10}$ kde uvádí termíny pro označení hlavního členu/predikátu vět jednočlenných/bezpodmětových v ruských i českých pracích.

V další části této kapitoly jsou podrobně popisovány gramatické fakty spadající pod termíny pro tradiční rozvíjející větné členy, tj. předmět, přívlastek a přístavek

7 Tamtéž, s. 54-77.

8 Tamtéž, s. 78-120.

9 Srov. např. FLÍDROVÁ, H. - ŽAŽA, S.: Sintaksis russkogo jazyka v sopostavlenii s češskim. Olomouc: Univerzita Palackého, Filozofická fakulta, 2005.

10 Tamtéž, s. 94-95. 
a př́slovečné určení, $\mathrm{s}$ důrazem na shody a rozdíly $\mathrm{v}$ obou syntaktických tradicích. O. Berger upozorňuje na užší nebo širší rozsah pojímání těchto větných členů v porovnávaných syntaktických teoriích. Širší pojetí se v české syntaxi týká např. př́slovečného určení, o čemž svědčí také velký počet jeho nových druhů, a tedy i termínů, zejména při detailních klasifikacích příslovečného určení, naopak vymezení předmětu je v české tradici poněkud užší. Srov. např. взмахнуть палками - v ruské tradici je substantivum pokládáno za předmět, zatímco v české za př́íslovečné určení prostředku $\mathrm{v}$ širokém smyslu. Tento nesoulad $\mathrm{v}$ pojímání některých větných členů v porovnávaných syntaktických teoriích navzájem, ale i uvnitř každé z nich, svědčí zároveň o nejednoznačnosti (synkretizmu) těchto členů, což je předmětem syntaktické synkretologie, s jejímiž současnými poznatky autorka rovněž pracuje.

Poslední část této kapitoly tvoří výklad větných členů vlastních pouze české rusistice nebo bohemistice. Patří sem na jedné straně nové větné členy, napřr. subjektové určení / sémantický subjekt a některé další, jimiž se syntaktikové snaží zmírnit dopad syntaktického synkretizmu a zpřesnit klasifikaci větných členů, třebaže se tím zvýší jejich počet, a na druhé straně český doplněk, s nímž se v ruské tradici nepracuje a př́slušný syntaktický fakt se tam hodnotí různě. Čeští rusisté dali mezi různými označeními pro doplněk přednost termínu дуплексив, který byl přejat od ruské lingvistky L. D. Česnokovové, v jejímž pojetí však má poněkud širší obsah než náš doplněk.

Závěr knihy tvoří Общue выводыl, ${ }^{11}$ tj. hutné a stručné shrnutí poznatků získaných konfrontační analýzou sledovaných termínů.

Monografie O. Berger je fundovaná práce podložená bohatou odbornou literaturou a přispívající $\mathrm{k}$ objasnění složité problematiky syntaktické terminologie v ruské a české syntaxi ve srovnávacím aspektu. Autorka se ujala náročného tématu, nebot termíny, které byly pro výzkum vybrány, patří v syntaxi ke stěžejním, o to je jejich zpracování záslužnější. O. Berger se evidentně neomezuje pouze na hledání jejich příslušných ekvivalentů ve druhém jazyce, ale sleduje jejich obsah i výklad, včetně uplatnění historického hlediska, $\mathrm{v}$ obou národních syntaktických teoriích. Hodnotu práce zvyšuje rovněž fakt, že je psána rusky a může být využivána také zahraničními rusisty. Jedná se o kvalitní prrínos do rusistické lingvistické literatury s možností využití této monografie nejen jako podkladu pro další bádání v oblasti syntaktické terminologie, ale i při výuce ruské filologie. 


\section{Literatura:}

BAUER, J. - MRÁZEK, R. - ŽAŽA, S.: Příruční mluvnice ruštiny pro Čechy. II, Skladba. Praha: Státní pedagogické nakladatelství, 1960.

BERGER, O.: Sintaksičeskije terminy v russkom i češskom jazykach: sopostavitel'nyj aspekt (na materiale vybrannych terminov). Brno: Masarykova univerzita 2021. ISBN 978-80-210-9807-7.

FLÍDROVÁ, H.: Nový pohled na větné členy v ruské a české syntaxi. Opera Slavica, 2021, 2, s. $73-76$.

FLÍDROVÁ, H. - ŽAŽA, S.: Sintaksis russkogo jazyka v sopostavlenii s češskim. Olomouc: Univerzita Palackého, Filozofická fakulta, 2005. ISBN 80-244-1104-o.

SLOVÁK, V.: Synkretizmus větných členů v ruštině a češtině. Sinkretizm členov predloženija v russkom $i$ češskom jazykach. Olomouc: Univerzita Palackého v Olomouci, 2020. ISBN 978-80-244-5617-1.

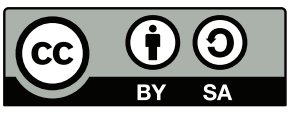

Toto dílo Ize užít v souladu s licenčními podmínkami Creative Commons BY-SA 4.0 International (<https:// creativecommons.org/licenses/by-sa/4.0/legalcode>). Uvedené se nevztahuje na díla či prvky (např. obrazovou či fotografickou dokumentaci), které jsou v díle užity na základě smluvní licence nebo výjimky či omezení príslušných práv.

\section{Nová slovenská publikace o ruském malířství}

FIGEDYOVÁ, M.: Обзор русской живописи от истоков до начала XX века. Brno: Tribun EU, 2019. ISBN 978-80-263-1532-2.

Marianna Figedyová přináší prostřednictvím své publikace Обзор русской живописи от истоков до начала $X X$ века ucelený přehled významných etap ruského výtvarného umění od 9. až do počátku 2o. století. Publikace je koncipována jako výukový text adresovaný především studentům Katedry rusistiky filozofické fakulty Univerzity sv. Cyrila a Metoda v Trnavě, zajisté však bude přínosem také pro širší okruh čtenářů jevících zájem o ruské výtvarné umění. Text seznamuje čtenáře se základními etapami rozvoje ruského výtvarného umění od zrodu ruské ikony až do příchodu ruské avantgardy na počátku 20. století. 